\title{
СТРАТЕГІЧНЕ УПРАВЛІННЯ ВИСОКОШВИДКІСНИМИ ПАСАЖИРСЬКИМИ ЗАЛІЗНИЧНИМИ ПЕРЕВЕЗЕННЯМИ
}

Овчиннікова В.О., к.е.н., доцент, Габєлков М.В., магістрант програми ТЕМПУС (УкрДУЗТ)

В статті обтрунтована необхідність застосування положень стратегічного управління під час розвитку високочвидкісних пасажирських залізничних перевезень. Проаналізовано проблеми розвитку пасажирських перевезень залізничним транспортом в Україні, а також впровадження швидкісного руху в державі. Досліджено досвід господарювання країн світу на світовому ринку високошвидкісних залізничних перевезень. Визначені стратегічні орієнтири інноваційного розвитку залізничного транспорту України. Удосконалено теоретичні положення стратегічного управління пасажирськими залізничними перевезеннями.

Ключові слова: управління, стратегія, стратегічне управління, розвиток, пасажсиські перевезення, залізничний транспорт.

\section{СТРАТЕГИЧЕСКОЕ УПРАВЛЕНИЕ ВЫСОКОСКОРОСТНЫМИ ПАССАЖИРСКИМИ ЖЕЛЕЗНОДОРОЖНЫМИ ПЕРЕВОЗКАМИ}

\author{
Овчинникова В.А., к.э.н., доцент,
}

Габелков М.В., магистрант программы ТЕМПУС (УкрГУЖТ)

В статье обоснована необходимость применения положений стратегического управления при развитии высокоскоростных пассажирских железнодорожных перевозок. Проанализировань проблемы развития пассажирских перевозок железнодорожным транспортом в Украине, а также внедрение скоростного движения в стране. Исследован опыт хозяйствования стран мира на мировом рынке высокоскоростных железнодорожных перевозок. Определены стратегические ориентиры инновационного развития железнодорожного транспорта Украины. Усовершенствованы теоретические положения стратегического управления пассажирскими железнодорожными перевозками.

Ключевые слова: управление, стратегия, стратегическое управление, развитие, пассажирские перевозки, железнодорожный транспорт.

\section{STRATEGIC MANAGEMENT BY HIGH-SPEED PASSENGER RAILWAY TRANSPORTATION}

\section{Ovchinnikova V.O., Candidate of Economic Sciences, Associate Professor Gabielkov M.V., Master of program TEMPUS (USURT)}

The article substantiates the necessity of applying the provisions of strategic management in the development of high-speed passenger rail transport. The problems of

(C) Овчиннікова В.О., Габєлков М.В.
Вісник економіки транспорту і промисловості № 59, 2017 
development of passenger transportation by rail in Ukraine, as well as introduction of highspeed traffic in the state are analyzed. The experience of managing the countries of the world in the world market of high-speed rail transportation is investigated. Strategic guidelines for innovation development of railway transport of Ukraine are defined. The theoretical positions of strategic management of passenger railroad traffic have been improved.

Keywords: management, strategy, strategic management, development, passenger transportation, railway transport.

Постановка

проблеми.

Залізничний транспорт залишається одним iз каталізаторів розвитку економіки будьякої країни, зокрема в Україні залізниця є: ключовим активом для забезпечення мобільності населення і єдності держави (саме на неї припадає $43 \%$ пасажирообігу); одним із найбільших платників податку (в 2016 році державі було виплачено 15 млрд. грн) та джерелом забезпечення 3\% ВВП економіки країни.

Крім того, українські залізниці мають одну з найбільших експлуатаційну протяжність головних колій, яка складає 19790 км, з яких електрифіковано 47,4\%, це $\epsilon$ однією 3 ключових переваг українського залізничного транспорту, однак зазначена перевага не використовується сьогодні в повній мірі для забезпечення конкурентоспроможності на світовому ринку залізничних перевезень, як і багато інших.

Про поступову втрату конкурентних позицій Укрзалізницю на світовому рику свідчать дані The Global Competitiveness Report 2016 - 2017, згідно яких Україна за критерієм розвитку залізничної інфраструктури посідає - 34 місце, в той час коли сусідні Польща та Російська федерація посідають 49 та 25 місця відповідно. У 2014 році даний критерій в України був на 25 місці в світі, коли у Росії та Польщі 31 та 70 місця відповідно.

Тобто залізничний транспорт функціонує в умовах мінливого та агресивного зовнішнього середовища, що негативно впливає на фінансово- економічний та відповідно технікотехнологічний стан галузі. Все це вимагає прийняття кардинальних рішучих дій, які б враховували зміни та імперативи зовнішнього середовища, а також базувалися б на явному економічному потенціалі галузі.

Ефективно здійснити зазначене можливо за рахунок використання методів та моделей стратегічного управління в системі менеджменту залізничного транспорту. В першу чергу це стосується високошвидкісних пасажирських перевезень, адже зміни в цьому виді діяльності залізничного транспорту кардинальні, а вітчизняні пасажирські перевезення в цьому бізнес-напрямку майже не змінилися.

Аналіз останніх досліджень i результатів. В статтю було закладено результати наукових досліджень стратегічного управління пасажирськими перевезеннями вітчизняних та закордонних вчених, зокрема: досліджень iз впровадження швидкісного руху В.Л. Диканя [1]; економічної ефективності впровадження високошвидкісних пасажирських перевезень Ю.С. Бараша та А.В. Момота [2]; аналіз світового досвіду розвитку залізничного транспорту та перспектив його розвитку в Україні О.С. Полтавської [3]; аналіз проблем розвитку пасажирських перевезень залізничним транспортом в Україні Д.М. Козаченка, Р.Г. Коробйової та А.В. Рубець [4]; аналіз стратегічних орієнтирів інноваційного розвитку залізничного транспорту України І.В. Токмакової, О.В. Хомотюк та P.O. Новікова [5]; забезпечення

Вісник економіки транспорту і промисловості № 59, 2017 
ефективності інноваційної діяльності на підприємствах залізничного транспорту В.О. Зубенко та Л.Ю. Коник [6]; розроблену стратегію розвитку ПАТ «Укрзалізниця» 2017-2021 роки [7]; стратегію розвитку холдингу «РЖД» на період до 2030 року [8]; дослідження В.П. Купріяновського, Г.В. Суконнікова, П.М. Бубнова, С.А. Синягова, Д.Е. Наміоту в напряму цифрової залізниці [9]; аналіз досвіду Великобританії в сфері економіки інновацій цифрової залізниці В.П. Купріяновського, П.В. Куренкова, Г.В. Бубнова, О.П. Дунаєва, С.А. Синягова та Д.Е. Наміоту [10].

Однак існуючий стан та рівень розвитку пасажирських залізничних перевезень свідчить про доцільність проведення наукових досліджень в зазначеній тематиці.

Постановка цілей. Метою статті $€$ удосконалення теоретичних положень стратегічного управління пасажирськими залізничними перевезеннями.

Виклад основного матеріалу. Для того, щоб займати гідне місце вітчизняному залізничному транспорту на світовому ринку високошвидкісних залізничних перевезень, в першу чергу слід дослідити зміни в цьому напрямку, які відбувалися в інших країнах світу. Досвід країн світу демонструє, що найбільшої ефективності в пасажирських перевезення залізничним транспортом можна досягти за швидкості руху - 200350 км / год, для таких швидкостей необхідна спеціальна інфраструктура та відповідний рухомий склад, що вимагає значних капіталовкладень для їх створення.

Високошвидкісні залізниці (що також називаються Lignes Grande Vitesse, або швидкісні лінії LGV) визначаються Міжнародним союзом залізниць та ЄС як стандартні, 3 допустимою максимальною швидкістю понад 200 км/год, або як нові лінії, 3 передбаченою максимальною швидкістю понад 250км/год. Усі високошвидкісні залізниці LGV Великобританії, Франції, Німеччини, Бельгії, Голландії, Іспанії та Італії, прокладені протягом останніх 30 років, мають проектну швидкість лінії 300км/год та більше [3].

Загальна

протяжність високошвидкісних залізничних магістралей у світі зараз складає 7000 км, зокрема 3750 км в Європі, причому високошвидкісні поїзди обслуговують також полігон протяжністю близько 20 тис. км звичайних залізничних ліній, реконструйованих для здійснення швидкісного руху. Процес проектування й будівництва нових ліній високошвидкісного руху не припиняється: так, поряд з розвитком високошвидкісної залізничної мережі Південної Європи (довжина якої до 2020 р. може становити приблизно 10 тис. км), передбачається зростання кількості високошвидкісних ліній у країнах Азії. Перше місце в рейтингу високошвидкісних магістралей займає Китай, де швидкість руху 350 км/год.

Лінія, якою курсують поїздирекордсмени поєднує Пекін і Шанхай. В 2011 році швидкість на даній ділянці знизилася до 300 км / год. Тепер оновлені потяги Fuxing їздять на 50 км / год швидше, а лінія повернула собі статус найшвидкісної залізниці в світі. «Потягикулі», які курсують між Шанхаєм i Пекіном вважаються найшвидшими в світі. Відстань між містами перевищує 1200 км. На швидкісному поїзді його можна подолати за 4 години 28 хвилин. Згідно з даними Google Maps, автомобілем цей маршрут займе не менше 13 годин. Лінія поєднує два найбільших міста, що забезпечує пасажиропотік в 100 млн осіб на рік. Вона була спроектована під рух із зазначеною швидкістю i поява нового поїзда фактично виводить іiі на плановий

Вісник економіки транспорту і промисловості № 59, 2017 
режим роботи. Особливо наголошується, що нові поїзди повністю зібрані в Китаї. Виробники стверджують, що провели 600 000 км тестових поїздок i гарантують безпеку мінімум на 30 найближчих років. Від старих потягів Fuxing відрізняється також додатковими зручностями: Wi-Fi, USB-порти, звичайні розетки. Поїзд оснастили автономною системою безпеки, яка може відреагувати на позаштатні ситуації і зупинити поїзд.

Влада Китаю планує пов'язати країну ще 3 17державами. Це надасть Китаю статусу світового лідера в галузі швидкісних залізничних перевезень, а протяжність високошвидкісних залізничних магістралей у країні перевищить $50 \%$ від загального обсягу подібних магістралей у всьому світі. Незважаючи на комфортабельність високошвидкісних поїздів, вони $\epsilon$ недоступними для великої категорії людей 3 низьким рівнем доходів. На відносно коротких маршрутах перевага високошвидкісних поїздів зовсім нівелюється високою вартістю проїзду. Поява поїздів з різними швидкостями руху дасть змогу пасажирам купувати дешевші квитки на "повільні" потяги, а також збільшить кількість зупинок [3].

Подібний проект зараз реалізується в Японії. Там планують експлуатувати поїзди-кулі на швидкості 360 км / год, але з'являться вони ще не скоро.

Серед країн СНД, які впроваджують високошвидкісний залізничний рух належить й Російська Федерація. Керівництво оператораперевізника «Российские Железные Дороги» (РЖД) в концепції розвитку галузі поставило наступні головні цілі розвитку високошвидкісних залізничних перевезень:

- поліпшення транспортних зв'язків між найбільшими містами та регіонами країни;
- розширення ряду послуг, що пропонуються пасажирам;

- підвищення інтероперабельності залізничного транспорту в галузі пасажирських перевезень;

підвищення транспортної мобільності населення підвищенні якості послуг, які пропонуються пасажирам [8].

Щодо залізничного транспорту в Україні, то слід зазначити, що під натиском міжнародних кредиторів влада України наважилася на реформу Укрзалізниці, яка була передбачена законодавчо ще у 2012 році.

3 початку 2015 p. Держадміністрація залізничного транспорту стала публічним акціонерним товариством «Українська залізниця» (далі ПАТ «УЗ»). Замість шести окремих залізниць і десятків підприємств з'явився один господарчий суб'єкт з 29 філіями. У результаті утворилися вертикально інтегровані структури за видами діяльності (вантажні та пасажирські перевезення, ремонт рухомого складу і т. д.). Крім того, структура компанії стає прозорою та зрозумілою для інвесторів. Реформування залізниці в Україні також включає використання системи закупівель «Prozorro», що дозволяє відкинути можливості корупційних схем у сфері закупівель, більш ефективно використовувати фінансові засоби ПАТ «УЗ» та вивести акціонерне товариство у стан ринкових відносин. Акціонування Укрзалізниці - ще одна 3 вимог міжнародних кредиторів (ЄБРР, Світового банку, Свропейського інвестиційного банку). Саме їх інвестиції можуть допомогти із розвитком галузі. Зокрема, йдеться про кошти на оновлення рухомого складу, поліпшення залізничного господарства і подальшу електрифікацію доріг [3]. Особливої уваги слід приділити одній із 29 філій - «Українській залізничній швидкісній компанії». Саме цей підрозділ займається перевезеннями у

Вісник економіки транспорту і промисловості № 59, 2017 
режимі прискореного руху. Станом на 1 вересня 2017 року в Україні курсують 15 швидкісних(прискорених) поїздів. "IНTЕРСІТІ+", 3 рухомим складом корейського виробництва HYUNDAI; двома поїздами "IHTEPCITI" чеського виробництва "SKODA", поїздами виробництва Крюківського вагонобудівного заводу із локомотивною тягою та поїзду ЕКр-1. Максимальна швидкість всіх видів рухомого складу становить 160 км/год.

За останні роки багато чого змінено, створено перепрофілювання діяльності підприємств залізничного транспорту (наприклад «УЗШК», яка займається швидкісними перевезеннями пасажирів), алесьогодні цього не достатньо для досягнення позитивного ефекту, необхідні істотні стратегічні рішення.

Слід зазначити, що спроби у даному напрямку вже є, так у 2017 році ПАТ УЗ представила стратегію розвитку на 2017-2021 роки, але ж в результаті досліджень 3'ясовано, що ця стратегія більш направлена на рішення тактичних задач, ніж стратегічних. В ній наголос робиться на аспекти властиві 4 технологічного устрою, i мінімум аспектів до устроїв більш високого рівня.

Якщо розглянути приклади залізниць країн світу, то, наприклад, ВАТ «Российские железные дороги» розглядають комплексну стратегію розвитку, в якій особлива увага приділяється інноваціям або ж концепції «цифрової (розумної) залізниці». А якщо розглянути приклад Великобританії, то там у 2012 році було опубліковано першу в галузі залізничну технічну стратегію (RTS), в якій описано, як інновації можуть дозволити зробити питомі витрати вдвічі менше, потужність залізниці можна буде збільшити в два рази, викиди вуглецю зменшити вдвічі i реалізувати новий досвід для клієнтів. У цей час рівень інвестицій в інновації був низьким, отже перший кроком стало збільшення кількості активності в області інновацій. Чотири роки по тому, дослідники та промисловість Великобританії почали активно співпрацювати і створили суттєві розробки за основними напрямками, що складаються більш ніж з 200 інноваційних проектів і програм. Це було одним 3 головних досягнень. Отримавши більше інновацій в стадії реалізації, британці порахували життєво важливим, щоб створити об'єднання інноваційних перетворень галузі в одну програму єдиний план. План, який фокусує зусилля, досвід та інвестиції, визначивши дії в порядку пріоритету.

Цей єдиний план передбачає базовий рівень - або пункти плану, проти яких можна зрозуміти актуальність i цінність будь-якого пункту з інновацій для діяльності всієї галузі. В даний час цей план виконується на чолі 3 новим технічним керівництвом групи, яка представляє групи Rail Delivery Group, Rail Supply GroupRail разом з урядом. Цей план визначає можливості, які дозволять залізниці Великобританії запропонувати більш широкі можливості для транспортування пасажирів і вантажів [10]. Отже такий план $є$ стратегічно зорієнтований на ефективний розвиток галузі швидкими темпами, задля отримання конкурентних переваг на ринку залізничних перевезень.

Для того, щоб створити подібну стратегію розвитку в Україні, необхідно сформувати концептуальні положення стратегічного управління залізними перевезеннями, які б враховували специфіку залізничних перевезень, що притаманна нашій країні.

Стратегічне управління - це таке управління, яке спирається на людський потенціал як основу організації, орієнтує виробничу діяльність на запити споживачів, гнучко реагує i проводить

Вісник економіки транспорту і промисловості № 59, 2017 
своєчасні зміни в організації, що відповідають виклику з боку оточення і дозволяють домагатися конкурентних переваг, що в сукупності дає можливість організації виживати в довгостроковій перспективі, досягаючи при цьому своїх цілей. Проблеми стратегічного управління найчастіше виникають в результаті дії численних зовнішніх чинників. Тому, щоб не помилитися у виборі стратегії, важливо визначити, які економічні, політичні, науково-технічні, соціальні та інші чинники впливають на майбутне організації.

В науковій літературі [12] основними принципами стратегічного управління обрано:

науково-аналітичного передбачення і розробки стратегії говорить про те, що для розробки стратегічного рішення недостатньо одних лише побажань i суб'єктивних передбачень. Необхідний аналіз попередньої діяльності організації, загальної ситуації в області іiі діяльності та динаміки іiі зміни. Необхідний також прогноз, а можливо, і розробка сценаріїв розвитку організації в найближчій і більш віддаленій перспективі;

2) обліку та узгодження зовнішніх $і$ внутрішніх факторів розвитку організації передбачає, що стратегічні рішення, прийняті на підставі врахування впливу тільки зовнішніх або тільки внутрішніх чинників, будуть неминуче страждати недостатньою системністю, що, в свою чергу, може вести до помилково прийнятим рішенням. Адже стратегічні рішення повинні бути вивіреними i ефективними, оскільки за ними стоять напрямки розвитку і наступні результати діяльності не тільки окремо взятої людини, але цілої організації;

3) відповідності стратегії і тактики управління організацією стверджує, що для забезпечення успішної діяльності організації необхідні і вивірена стратегія, i ефективна тактика. При цьому ефективна діяльність організації можлива за умови, коли тактика організації відповідає іiі стратегіï, а формування стратегії враховує реальні можливості вирішення тактичних завдань;

4) пріоритетності людського фактора підкреслює, що ні стратегія, ні тактика організації не можуть бути реалізовані, якщо вони не будуть сприйняті як керівництво до дії іiі персоналом, і в першу чергу iii менеджерами, яким делеговано право прийняття управлінських рішень на ввіреній їм ділянці;

5) визначеності стратегії i організації стратегічного обліку і контролю вказує на те, що розуміння персоналом поставлених перед ним завдань має випливати з чітких формулювань стратегії організації. Нечітко сформульовані стратегічні цілі організації можуть призводити до неоднозначного їх тлумачення різними службами організації;

6) відповідності стратегії організації наявних ресурсів вказує на те, що без забезпечення ресурсами (які включають не тільки сировину, матеріали, комплектуючі, енергію, а й персонал, інформацію, ділових партнерів, імідж і т. д.) Реалізація стратегії, якою б чудовою вона не була, виявляється частково або повністю під загрозою;

7) відповідності стратегії організації наявним технологіям підкреслює, що досягнення будь-якої мети, реалізація будьяких задумів можливі, тільки якщо в розпорядженні організації $є$ технології, за допомогою яких можна послідовно вирішити конкретні завдання, пов'язані зі стратегічною метою [12].

Однак зазначених принципів не достатньо для побудови комплексної системи стратегічного управління пасажирськими перевезеннями залізничним транспортом. Базуючись на специфіці залізничного транспорту слід виокремити принцип самоідентифікації чи зворотного впливу, який вказує на те, що залізничний транспорт $є$ рушійною силою

Вісник економіки транспорту і промисловості № 59, 2017 
змін в економіці, тут виникає необхідність вибору стратегії яка б передбачувала розвиток не тільки залізничного транспорту, а й національної економіки в цілому.

Відповідно до запропонованого принципу до стратегічних перспектив технологічного розвитку залізничного транспорту України поряд з інноваційними енерго- i ресурсоефективності системами для рухомого складу та інфраструктури слід віднести створення «розумної» залізниці. «Розумна» залізниця це єдиний інформаційний комплекс взаємопов'язаних систем обробки даних і систем автоматики в управлінні перевезеннями.

Розвиток інформаційних технологій лежить в основі стратегії підвищення привабливості залізничних послуг, що представляються пасажирам . При цьому IT-технології повинні забезпечити створення:

- умов, що забезпечують підтримку послуги пасажирам в режимі реального часу в будь-якому місці, в будь-який час, 3 урахуванням кількох видів транспорту, включаючи планування маршруту, покупку єдиних квитків та бронювання, супровід по маршруту, надання додаткових послуг;

- широкий спектр логістичних додатків для реалізації логістичних послуг на вибір клієнта, включаючи рівень 4PL i вище;

- інтелектуальних і гнучких систем управління транспортом 3 метою оптимізації архітектури і операційних систем залізничної мережі на рівні маршруту і окремого поїзда;

- взаємозв'язок і обмін інформацією для інтелектуальних транспортних систем.

В області організації пасажирських перевезень на базі «цифрових технологій» формуються світові стандарти ведення юридичної засновані на передовому досвіді забезпечення максимального рівня інтероперабельності транспортних систем. Комплекс послуг, що надаються пасажирам на всіх етапах поїздки від планування до надання широкого спектра додаткових сервісних послуг в пункті призначення, включаючи забезпечення їх особистої безпеки, може бути реалізований за рахунок:

- максимального використання мобільних пристроїв різних цифрових стандартів зв'язку та відповідних функціональних додатків, що забезпечують вибір параметрів подорожі: швидкість, комфорт і інші індивідуальні умови;

- створення можливості передачі і отримання інформації в поїздках на залізничному транспорті в режимі реального часу на вокзалах, в транспортнопересадочних вузлах і поїздах, завдяки чому реалізуються можливості on-line замовлення послуг, отримання інформації про поїздку та ін.;

- впровадження інтелектуальних систем управління вокзалами, що забезпечують функції інтелектуальних комплексів, що передбачають: гнучке реагування на динамічні зміни обсягів, структури, характеру та спрямованості пасажиропотоків;

- реалізацію принципу «постійна інформованість пасажирів» на основі інтерактивного інформування, візуальної навігації та інших форм забезпечення мобільності різних категорій пасажирів на вокзалах і в транспортно-пересадочних вузлах, в т.ч. інтерфейс поїзд / платформа;

- маркетинговий інтерактивний вплив, який формує сценарії поведінки пасажирів на території транспортних об'єктів, та відповідно гнучку технологію їх обслуговування;

створення

системи інтелектуального управління інженерною інфраструктурою вокзального комплексу [9].

Для реалізації клієнтоорієнтованої політики в області пасажирських перевезень 3 використанням IT-технологій повинні бути реалізовані системи

Вісник економіки транспорту і промисловості № 59, 2017 
керування пасажирськими перевезеннями нового покоління, що забезпечують:

- облік попиту і рівня мобільності населення для територій різного масштабу - від міжнародного до локального рівня, i передбачення впливу демографічних змін на потреби клієнтів;

- виділення трендів в оцінці якості послуг пасажирам послуг, а також необхідних змін для збереження збільшення обсягів перевезень в різних сегментах;

- розвиток i вдосконалення інформаційно-аналітичних систем, що використовуються для планування пасажирських перевезень, моніторингу мобільності населення та технічного забезпечення перевезень в різних секторах: високошвидкісних, швидкісних, далеких пасажирських, міжобласних і приміських. [8]

Висновки. В найближчий час в залізничній галузі України високошвидкісні перевезення (до 300 км/год) ймовірно будуть не можливі. Це, перш за все, викликане специфікою інфраструктури на таких швидкостях, а побудова її в умовах України не $\epsilon$ простою задачею - різноманітний рельєф, велика кількість кривих ділянок та однією 3 найважливіших причин $є$ фінансова неспроможність побудови. Розглянувши світовий досвід в галузі швидкісних i високошвидкісних перевезень, сучасні досягнення науково-технічного прогресу та зіставивши його із досвідом та поточним станом залізничної галузі в Україні, можна зробити висновки:

1. Обраний шлях в напрямку швидкісного (прискореного, до 160 км/год) руху $\epsilon$ на даний час найперспективнішим для України.

2. Розширення сітки швидкісних перевезень на території країни не тільки породжує попит та підвищує мобільність населення, але i зобов'язує залізничний транспорт все більше i більше задовольняти попит, а це можливо лише за умови підвищення швидкостей руху.

3. Для подальшого розвитку залізничного транспорту України необхідне створення та впровадження ефективної стратегії розвитку зосередженої на передових технологіях.

4. Для створення дієвої стратегії розвитку пасажирських перевезень доцільно скористатися запропонованими концептуальними положеннями.

Базуючись на цьому, i виконанні всіх умов, залізничний транспорт України може стати не тільки високо конкурентоспроможним на ринку швидкісних пасажирських перевезень, а й створити позитивний імідж всієї держави та підвищити інвестиційну привабливість економіки України в цілому.

\section{СПИСОК ВИКОРИСТАНИХ ДЖЕРЕЛ}

1. Дикань В. Л. Скоростное движение железнодорожного транспорта в мире и перспективы его развития в Украине / В. Л. Дикань // Вісник економіки транспорту та промисловості. - 2010. - № 32. - C. 15-25.

2. Економічна ефективність високошвидкісних пасажирських залізничних перевезень в Україні [Текст] : монографія / Ю. С. Бараш, А. В. Момот. Дніпропетровськ : Дніпропетр. нац. ун-т залізн. трансп. ім. акад. В. Лазаряна, 2015. $137 \mathrm{c}$.

3. Світовий досвід розвитку залізничного транспорту та перспективи його розвитку в Україні / О.С. Полтавська// Вісник економіки транспорту та промисловості. - 2014.- С. 473-475;

4. Проблеми розвитку пасажирських перевезень залізничним транпортом в Україні / Д.М. Козаченко, Р.Г. Коробйова, А.В. Рубець// Збірник наукових праць ДНУЗТ ім. акад. В.Лазаряна. - 2016. №12. - С.46-49.

Вісник економіки транспорту і промисловості № 59, 2017 
5. Стратегічні орієнтири інноваційного розвитку залізничного транспорту України/ I.В. Токмакова, О.В. Хомотюк, Р.О. Новіков// Вісник економіки і промисловості. - 2016. - №55. - С75-77.

6. Забезпечення ефективності інноваційної діяльності на підприємствах залізничного транспорту/ В.О. Зубенко, Л.Ю. Коник// Вісник економіки і промисловості. - 2015. - №49. - С.179-180.

7. Основні аспекти стратегії розвитку ПАТ «Укразілзниця» 2017-2021 роки [електронний ресурс] - Режим доступу: http://agreca.ua/oprilyudnenoosnovni-aspekti-strategiyi-rozvitku-patukrzaliznitsya-na-2017-2021-roki

8. Стратегия развития холдинга «РЖД» на период до 2030 года(основные положения) [електронний ресурс] - Режим доступу: http://doc.rzd.ru/doc/public/ru?
STRUCTURE_ID=704\&layer_id=5104\&refe rerLayerId $=5101 \& i d=6396$

9. Цифровая железная дорога прогнозы, инновации, проекты / В.П. Куприяновский, Г.В. Суконников, П.М. Бубнов, С.А.Синягов, Д.Е. Намиот// International Journal of Open Information Technologies. - 2016.- №9. - C.34-41.

10. Экономика инноваций цифровой железной дороги. Опыт Великбритании / В.П. Куприяновский, П.В. Куренков, Г.В. Бубнова, О.П. Дунаев, С.А. Синягов, Д.Е. Намиот // International Journal of Open Information Technologies. - 2017.- №3. C. 79-85. 11.

Энциклопедия производственного менеджера [електронний ресурс] - Режим доступу: http://www.up-pro.ru/encyclopedia/ strategicheskoe-upravlenie.html

\title{
УДК 658.7:656.2
}

\section{ПЕРСПЕКТИВИ РОЗВИТКУ ТРАНСПОРТНО- ЛОГІСТИЧНИХ СИСТЕМ УКРАЇНИ}

\author{
Устенко М. О., к.е.н., доцент, \\ Івачкевич В.С., махістр (УкрДУЗТ)
}

\begin{abstract}
У даній статті розглянуто основні перспективи розвитку транспортнологістичних систем, яких сприятимуть збільшенню перевезень $i$ розвитку транспортної галузі в цілому, визначено напрямки розвитку $i$ заходи для покращення транспортної логістики в Україні на сучасному етапі. Також виділено основні функиіі транспортної логістики на підприємствах та обгрунтовано важливість інтегруючої функиії в сучасних умовах розвитку. Зроблено висновок, щу поступова цілеспрямована інтеграчія транспортного комплексу Украӥни до загальноєвропейської та світової транспортної системи иляхом розвитку міжнародних транспортних коридорів може забезпечити не лише додаткові надходження до бюджету, а й стимулювати інвестиційну активність, залучення іноземного капіталу, вдосконалення технологій транспортування, транспортної інфраструктури краӥни в иіілому та економічний розвиток регіонів.
\end{abstract}

Ключові слова: логістика, транспортно-логістична система, логістичний підхід, інтеграція, підприємство, транспорт

(C) Устенко М.O., Івашкевич В.С.
Вісник економіки транспорту і промисловості № 59, 2017 